\title{
IMPROVEMENT OF WORKPLACE ERGONOMICS IN ATRIUM-TYPE BUILDINGS
}

\author{
Piia Tint ${ }^{\#}$, Georgi Hrenov, Virve Siirak, Ada Traumann, Marina Kritševskaja, \\ and Deniss Klauson
}

Tallinn University of Technology, Ehitajate 5, Tallinn, 19086, ESTONIA

\# Corresponding author

Communicated by Modra Murovska

\begin{abstract}
The aim of the study was to improve the indoor quality and ergonomics of workplaces in atriumtype buildings. The investigated atrium-type building has the atrium (15×30 metres) inside. The roof of the atrium is built from glass and there is a break between the walls and the roof. It gives the possibility for workers in rooms closed to the atrium to have some fresh air. Nevertheless, there are problems caused by shortage of natural light, high concentrations of $\mathrm{CO}_{2}$ and low room temperature in winter. The main results of the investigation were: the design of the workplaces needs to be carried out in parallel to the construction of the building; later it is difficult to improve conditions in the workplace; the air temperature in workrooms depends on the room location in the building and in winter, rooms closed to the atrium are cold; the concentration of $\mathrm{CO}_{2}$ exceed limits in rooms where windows cannot be opened. Workers are endangered by developing sick building syndrome. The concentration of dust is under the limits, but the problem of dusty air was raised by the workers. Some ergonomic improvements are possible and corresponding recommendations were given to the employers.
\end{abstract}

Key words: atrium-type buildings, natural lighting, microclimate, sick-building syndrome, concentration of $\mathrm{CO}_{2}$, workplace design.

\section{INTRODUCTION}

The world practice of designing atrium-type buildings to improve the indoor climate is used both in cold and warm climate countries (Voeltzel et al., 2001; Sharples and Lash, 2007; Song, 2007; Pan et al., 2009; Yunus et al., 2010; Sadrzadehrafiei et al., 2011). The atrium-type buildings are mainly used as commercial centres, but also as large educational buildings (Tint and Traumann, 2012a).

In the present study, the indoor climate, lighting and ergonomic design of workplaces in the workrooms of an atrium-type building (built in 2009) of a university were investigated.

In the Estonian Standard EVS-EN 15251:2007, the demands for indoor climate (IC) quality in office-rooms are given for the air temperature, humidity, velocity (ventilation), carbon dioxide concentration, noise, and lighting. The Estonian standard EVS 894:2008 (Daylight in dwellings and offices) gives more attention on the importance of natural lighting and possibilities to overcome shortages of natural lighting. The investigation of the air quality in offices and in residential buildings has become more and more important. The concentration of carbon dioxide $\left(\mathrm{CO}_{2}\right)$ has in- creased outdoors and therefore the indoor concentrations have also have become more uncomfortable to the people working inside (Stavova et al., 2007). Mechanical ventilation (Woods et al., 2009) no longer satisfies the comfort demands of workers. The windows in the office-rooms of atrium-type buildings have to be openable.

During the 1970s energy crisis, buildings were designed to be airtight and windows that cannot be opened became a common practice of building design. It is now clear that such airtight buildings create problems. Because of inadequate ventilation to the outside, the air pollutants inside the buildings have to be removed. Health problems due to indoor air pollution can range from nose, eye, and throat irritation and aggravation of asthma to increased risk of lung cancer. Biological sources of indoor air pollution include mould, mildew, fungi, and bacteria (Schleibinger et al., 2008). Exposure to small amounts of indoor air pollutants can cause minor irritations, such as dry, scratchy eyes and throats, or headaches. However, in large concentrations pollutants can lead to dizziness, tiredness, and nausea, and rashes. Although anyone can suffer from indoor air pollution, the most susceptible groups are the ageing workforce, and persons with respiratory ailments like bronchitis, asthma, or emphysema. Nowadays, airtight windows are 
used in the office-rooms close to the atrium in atrium-type buildings (Tint and Traumann, 2012a). The physical environment of the workroom is important as it may induce stress in individuals and thereby reduce the overall results of cognitive endeavours of scientific and office workers. EVS-EN 15251:2007 originates from different (I to IV) categories of comfort.

Numerous studies both in Europe and North America have indicated that non-specific symptoms related to occupancy in office buildings (Bako-Biro et al., 2004; Fang et al., 2004; Saari et al., 2006) and attributed to poor air quality are common among office workers and that there is considerable variation in the prevalence of symptoms among buildings (Jones, 1999; Seppänen et al., 1999). These symptoms are generally referred to as sick building syndrome (SBS) symptoms. The SBS has become common due to the construction of buildings designed to be energy-efficient with air conditioning systems and unopenable windows (Berardi et al., 1991). SBS is characterised by: eye, nose and throat irritation, sensation of dry mucous membranes and skin erythema (skin redness), mental fatigue, headaches, high frequency of airway infections and cough, hoarseness, wheezing, itching and non-specific hypersensitivity, nausea and dizziness. SBS is often also characterised by other non-specific symptoms, such as nasal dryness, nasal congestion (stuffy, blocked nose), nasal excretion (runny nose), pharyngeal symptoms, difficulty in concentration, and difficulty in breathing and tight chest (Seppänen et al., 1999). The term 'SBS' is used primarily when the agents causing the symptoms are unidentified and the symptoms do not indicate a specific known disease. SBS symptoms/complaints appear during the workday and improve or disappear on the weekend. Despite several studies aimed at establishing the pathogenetic role of microorganisms, chemical pollutants and microclimate in such environments, the aetiological factors are usually difficult to identify (Berardi et al., 1991).

Natural ventilation in the workrooms is as important as the natural lighting. There are of course problems in winter as we have to preheat the air (Woods et al., 2009).

Natural light is associated with lower fatigue and reduced eyestrain. With natural lighting of the rooms the contact with outdoor environment remains for the worker (DeKay, 2010).

The body uses natural light similar to food and water, as it stimulates essential biological functions (nervous and endocrine system).

There are a number of factors that can limit visual functions of the worker, such as artificial lighting or daylight deficiency, visual correction, visual angle and distance, flicker, contrast etc. Workers are influenced psychologically and physiologically by different spectrums provided by natural and the artificial lighting. The atrium roof profile and structure influence very much the natural light transmittance: the roof lets through $20 \%$ and $80 \%$ of the light (Rennie and Parand, 1998).

The aim of the study was to survey indoor climate quality and workplace management to provide recommendations for improving working conditions and ergonomics of workplaces (Graves and Tardiff, 2006) for office workers.

\section{MATERIALS AND METHODS}

Characteristics of the building and the workrooms investigated are given in Figures 1-2.

Measurements made in the work environment are based on ISO, EN DIN, EVS standards: EVS-EN-ISO 7726:2003 "Thermal environments - Instruments and methods for measuring physical quantities"; EVS-EN 15251:2007 "Indoor environmental input parameters for design and assessment of energy performance of buildings addressing indoor air quality, thermal environment, lighting and acoustics", EVS-EN 12464-1:2011 "Light and lighting. Lighting of work places. Part 1: Indoor work places", EVS 891:2008 "Measurement and evaluation of electrical lighting in working places". The measuring equipment used for microclimate: TESTO 435. The device TESTO 435 also enables

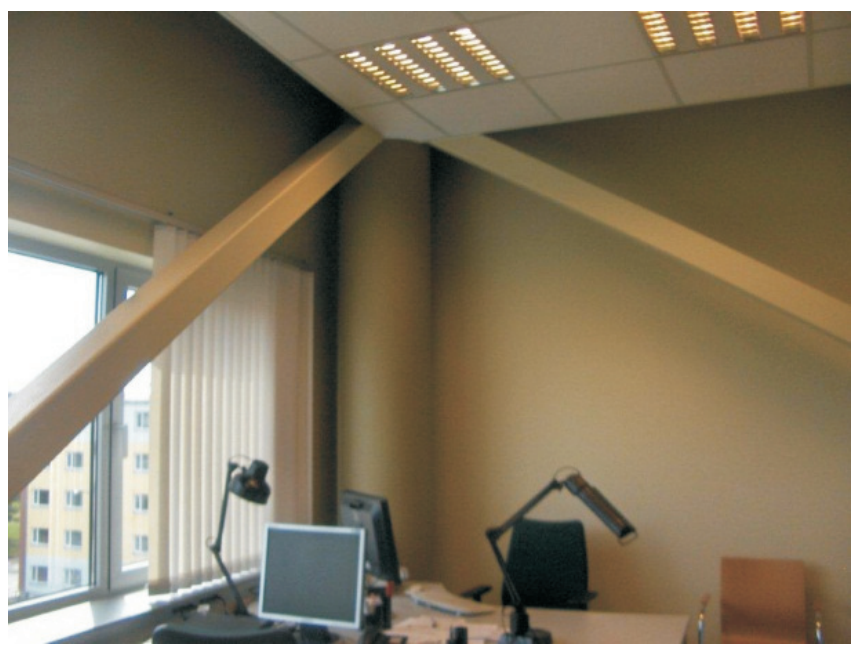

Fig. 1. Non-ergonomically designed workroom.

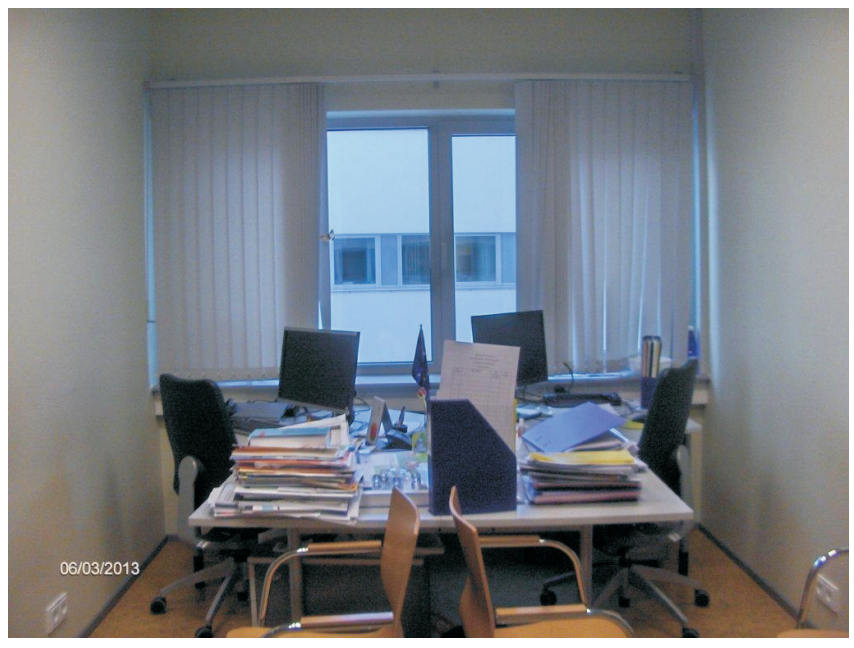

Fig. 2. The investigated workroom $\boldsymbol{A}$ in the building, closed to the atrium. 
measurement of $\mathrm{CO}_{2}$ concentration. Measurements of lighting in workplaces and from monitors were performed using the light-metre TES 1332 (ranges from 1-1500 lx). Lighting was measured on the worktable, on the monitor and on the keyboard. Lighting was measured at local workplaces (normally at a height $0.80 \mathrm{~m}$ above floor level), where a suitable measuring grid was applied. Dust was measured with a HazDust EPAM-5000.

\section{RESULTS}

Indoor climate conditions (bad microclimate, lighting problems, ergonomics of the workplace) can cause the health problems for office workers. Therefore, these three indoor climate components were investigated thoroughly.

Indoor air measurements. The exposure limits given in the standard EVS-EN for the indoor climate in three comfort classes 15251 are presented in Table 1. Data on estimated indoor climate conditions are given in Table 2. The air temperature in the offices was sometimes (in winter) under the norm $\left(<20-22{ }^{\circ} \mathrm{C}\right)$. Each of the investigated rooms had mechanical ventilation above the door ( 5 metres from the window). The mechanical ventilation in the rooms has been monitored for three years and the best results have been attained (cold air is no longer blowing on the workers). The relaxation time for heating the indoor air with the pre-heating ventilation systems in cold outdoor temperatures was too long, and therefore it was continuously cold in the rooms. The rooms are equipped with radiators, but in the rooms closed to the atrium they do not switch on until the room temperature is below 16 degrees. The relative humidity in winter was very low (10-15\%), which caused dry skin problems to workers. There was a bad smell in some of the rooms on the first floor that is closed to the atrium (biological tests were carried out, but fungi were not found). The indoor air was not dusty (measurement results were under the limit $0.0050 \mathrm{mg} / \mathrm{m}^{3}$ ), but not fresh (felt by the workers). Therefore, the rooms needed to be ventilated naturally by opening windows in the beginning of the workday and during lunch break.

The atrium-facing rooms were very comfortable in summer when compared to those that were closed to the outside wall. The atrium-facing rooms were not over-heated in summer. Natural lighting in winter was at intensity $50 \mathrm{~lx}$ to 100 lx in rooms closed to the atrium. For workroom $A$ (Fig. 2) the opposite windows were very close (other staff were working there), and the researchers in this room often worked with blinds-covered windows. This reduced the entrance of the natural light into the room even more.

The ergonomics of workplaces. Figure $3 \mathrm{a}, 3 \mathrm{~b}$, and $3 \mathrm{c}$ show the layout of tables and chairs in rooms. The workspace is small for two persons. Tables and chairs were purchased for the entire four-storey building at the start of operation in the building. All tables and chairs have the same size, regardless of the workers' anthropological features. The best of these three possibilities can be considered that depicted in Figure 3b. In this case, light enters from the left side for both of the workers (which is the optimal condition if they are right-handed); it is possible to open the window. In the present arrangement of the tables shown in Figure 3a, it is not possible to open the window, because the window stop is in the middle of the large window-wall and short workers reach the window to open it (the indoor interior was designed without consideration of the anthropological features of the workers). Such a conclusion was made based on the fact that the educational staff members were not

Table 1

PERMITTED INDOOR CLIMATE NORMS IN OFFICE-ROOMS (EVS-EN 15251:2007)

\begin{tabular}{|c|c|c|c|c|c|}
\hline $\begin{array}{l}\text { Category of comfort of } \\
\text { the room } \\
\text { (I- assessed as the best } \\
\text { room) }\end{array}$ & $\begin{array}{c}\text { Indoor air } \mathrm{CO}_{2} \\
\text { concentration (measured), } \\
\text { ppm }\end{array}$ & $\begin{array}{l}\text { Indoor air } \mathrm{CO}_{2} \text { concentration con- } \\
\text { sidering the mean measured out- } \\
\text { door } \mathrm{CO}_{2} \text { level } 400 \text { ppm }\end{array}$ & $\begin{array}{l}\text { Air temperature, } \\
{ }^{\circ} \mathrm{C} \\
\text { summer/winter }\end{array}$ & Air humidity, $\%$ & Lighting, 1x \\
\hline I & 350 & 750 & $25.5 / 21.0$ & $>30$ & 500 \\
\hline II & 500 & 900 & $26.0 / 20.0$ & $>25$ & 500 \\
\hline III & 800 & 1200 & $27.0 / 19.0$ & $>20$ & 500 \\
\hline
\end{tabular}

Table 2

RESULTS OF MEASUREMENTS INDOORS IN ATRIUM-TYPE BUILDINGS (2012-2013)

\begin{tabular}{|c|c|c|c|c|c|c|c|}
\hline \multirow[t]{2}{*}{ Room type } & \multicolumn{2}{|c|}{$\begin{array}{c}\text { Indoor air temperature, }{ }^{\circ} \mathrm{C} \text {, } \\
\qquad \mathrm{U}=0.6{ }^{0} \mathrm{C}\end{array}$} & \multicolumn{2}{|c|}{$\begin{array}{l}\text { Indoor air humidity, } \% \text {, } \\
\qquad U=2.0 \%\end{array}$} & \multirow[t]{2}{*}{$\begin{array}{l}\text { Lighting, } 1 \mathrm{x}, \\
\mathrm{U}=10.4 \%\end{array}$} & \multirow{2}{*}{$\begin{array}{c}\begin{array}{c}\text { Concentration of } \\
\text { carbon dioxide, } \\
\text { measured }\end{array} \\
\mathrm{CO}_{2}, \\
\mathrm{ppm} \\
\mathrm{U}=10 \%\end{array}$} & \multirow{2}{*}{$\begin{array}{c}\text { Concentration of } \\
\text { dust in the air } \\
\mathrm{mg} / \mathrm{m}^{3} \\
\mathrm{U}=10 \%\end{array}$} \\
\hline & $\begin{array}{l}\text { Cold } \\
\text { season }\end{array}$ & $\begin{array}{l}\text { Warm } \\
\text { season }\end{array}$ & Cold season & Warm season & & & \\
\hline Rooms close to the atrium & $18-20$ & $20-24$ & $10-21$ & $35-65$ & $433-1160$ & $541-897$ & 0.0015 \\
\hline Rooms closed to outdoors & $17-20$ & $22-28$ & $15-30$ & $40-70$ & $690-1209$ & $478-1152$ & 0.0011 \\
\hline
\end{tabular}

$\mathrm{U}$, the uncertainty of measurements

The dust concentration in the smoking room was $0.099 \mathrm{mg} / \mathrm{m}^{3}$ 
a

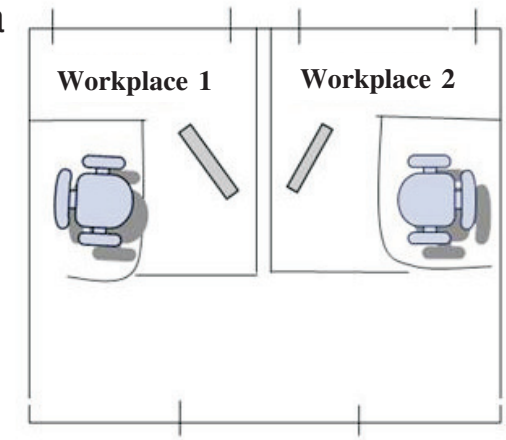

b

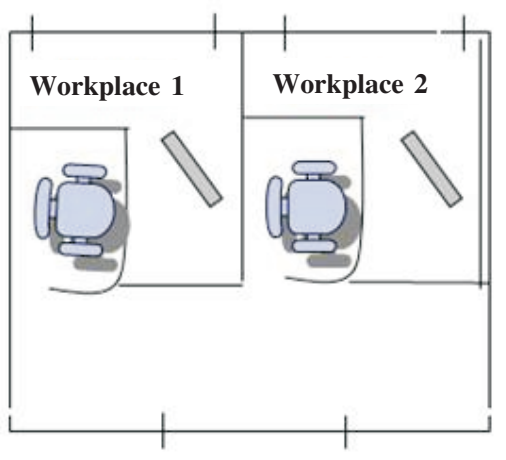

C

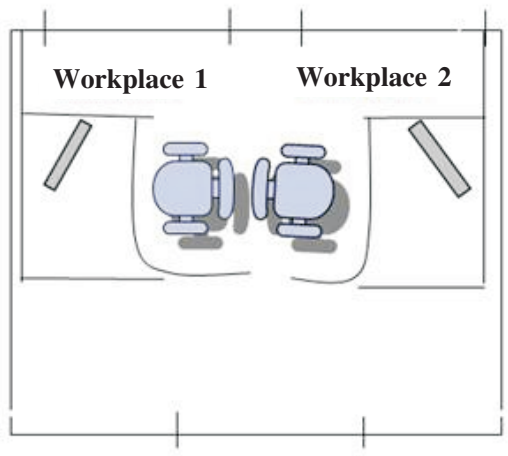

Fig. 3. Workroom $\boldsymbol{A}$ with two workplaces (area $12 \mathrm{~m}^{3}$ ). The ergonomic solutions (a, b, c)

present in the same time in the room. Simultaneous presence of workers in a room takes place 2-3 times a week and not for the whole working day.

\section{DISCUSSION}

The indoor air etc. problems in the same workplace can very much differ (Mergi, 2007; Geelen et al., 2008; Tint et al., 2012b). Therefore, an individual approach for every workplace has to be carried out considering the anthropological features etc. of the worker who will work in the specific workplace (Tayyari and Smith, 1997; Fernandez, 2002).

Info-technology workers often work in under-lighted working conditions although there are possibilities to increase (artificial) lighting to normal limits (400-500 lx).

The ergonomic use of laptops is achieved with docking stations, such that the worker will also use a large monitor. Some young workers like to use laptops in the dark (without artificial lighting), which can have negative impact on worker health years later (Brooks, 2005; Middlesworth, 2015).

If a workplace is designed ergonomically, it is possible to reduce the possibility of developing musculoskeletal disorders (MSDs), as strain in the body decreases. These diseases (MSDs) are the most common reason for a decrease of productivity of employees in the workplace (Lee, 1999; Oha et al., 2013). Chairs need to provide lumbar support; otherwise, the workers' body leans toward the table causing strain in the neck, shoulders and back (Hägg, 2000).

As ceiling lamp placement usually cannot be rearranged to avoid glare and inconvenience of workers regarding the illuminance sources (usually only the number of lamps turned on can regulated), then the workstation placement in relation to windows and ceiling lamps needs to be planned. Good ergonomic planning can increase visual comfort of workers and have a positive effect on their muscle- and joint comfort (Vilcane et al., 2015).

Occupational illnesses develop by stages. In the first stage, the rehabilitation is effective and the worker can return to work after some weeks after treatment. In the second stage, treatment is possible, but it takes more time and sometimes the worker has to change the work character to avoid being disabled in the future. Recovery from the third stage of the disease is not possible, but it is possible to use some rehabilitation methods to alleviate the suffering of affected persons. Managers and work environment specialists can influence the prevention of MSDs by the improvement of workplace ergonomics, which needs to be done before health disturbances occur.

The indoor air and other problems in the same workroom are specific to the particular case. Therefore, an individual approach for every workplace has to be implemented, considering the anthropological and other features of the worker who will work in the specific workplace.

The $1^{\text {st }}$ (the best) category of comfort (EVS-EN 15251) is achieved when the workers themselves can design the workplace and work with computers occurs as a part of alternative other work activities. Medical examinations are obligatory in case of work with computers once every three years (Anonymous, 1999). If the computer workers do not adhere to legislation on computer work, by taking work home, then the risk for developing MSDs is high already at a young age.

\section{ACKNOWLEDGEMENTS}

The work was supported by the INTERREG IVA Project CB52 WASI 'Work Ability and Social Inclusion' and the Estonian project SF0140022s10 'Chemical Engineering Aspects in Environmental Risk Assessment' (Estonia).

\section{REFERENCES}

Anonymous (1999). Ergonomics Plus Inc. Occupational Health and Safety Act of Estonia, passed 16.06.1999. State Gazette of Estonia. RTI 1999, 60, 616. Available at: http://ergo-plus.com/musculoskeletal-disorders-msd/ (accessed 8 September 2015).

Anonymous (2007). EVS-EN 15251:2007. Indoor environmental input parameters for design and assessment of energy performance of buildings addressing indoor air quality, thermal environment, lighting and acoustics. Estonian Centre for Standardisation (in Estonian).

Anonymous (2010). EVS 894:2008+A1:2010. Daylight in Dwellings and Office. Estonian Centre For Standardisation (in Estonian). 
Bako-Biro, Z., Wargocki, P., Weschler, C.J., Fanger, P. O. (2004). Effects of pollution from personal computers on perceived air quality, SBS symptoms and productivity in office. Indoor Air, 14, 178-187.

Berardi, B. M., Leoni, E., Marchesini, B., Cascella, D., Raffi, G. B. (1991). Indoor climate and air-quality in new offices: Effects of a reduced air-exchange rate. Int. Arch. Occup. Environ. Health, 63, 233-239.

Brooks, A. (2005). Ergonomics approaches to office layout and space planning. J. Facilities, 16 (3/4), 73-78.

DeKay, M. (2010). Daylighting and urban form: an urban fabric of light. $J$. Archit. Planning Res., 27 (1), 33-56.

Fang, L., Wyon, D. P., Clausen, G., Fanger, P. O. (2004). Impact of indoor air temperature and humidity in an office on perceived air quality, SBS symptoms and performance. Indoor Air, 14 (Suppl 7), 74-81.

Geelen, L. M. J., Huijbregts, M. A. J., Ragas, A. M. J., Bretveld, R. W., Jans, H. W. A., Van Doorn, W. J., Evertz, S., Van Der Zijden, A. (2008). Comparing the effectiveness of interventions to improve ventilation behavior in primary schools. Indoor Air, 18, 416-424.

Fernandez, J.E. (2002). Ergonomics in the workplace. J. Facilities, 13 (4), 20-27.

Graves, C. G., Tardiff, T. G. (2006). Office equipment and supplies: A modern occupational health concern? Amer. J. Epidemiol., 152, 593-594.

Hägg, G. M. (2000). Human muscle fibre abnormalities related to occupational load. Eur. J. Appl. Physiol., 83, 159-165.

Jones, A. P. (1999). Indoor air quality and health. Atmospheric Environ., 33, 4535-4564.

Lee, K. S. (2005). Ergonomics in total quality management: How can we sell ergonomics to management? J. Ergon., 48 (5), 547-558.

Mergi, C. A., Al-Dawoud, A.-S. (2007). Integration of ventilation in the design of commercial building: Application to atrium buildings in hot/humid climate. Archit. Environ., 6, 14-27.

Middlesworth, M. (2015). The definition and causes of musculoskeletal disorders (MSDs). Available at:

http://ergo-plus.com/musculoskeletal-disorders-msd/ (accessed 8 September 2015)

Oha, K., Viljasoo, V., Merisalu, E. (2010). Prevalence of musculoskeletal disorders, assessment of parametres of muscle tone and health status among office workers. Agron. Res., 8 (Special Issue 1), 192-200.

Pan, Y., Li, Y., Huang, Z. (2009). Study on energy modelling methods of atrium buildings. In: Proceedings of the 11th International IBPSA Conference: Building Simulation 2009. Glasgow: Simulation Research Group, pp. 250-257.

Received 9 December 2015
Rennie, D., Parand, F. (1998). Environmental Design Guide for Naturally Ventilated and Daylit Offices. Branknell, UK: BSRIA Ldt. 64 pp.

Saari, A., T. Tissari, T., Valkama, E., Seppänen, O. (2006). The effect of a redesigned floor plan, occupant density and the quality of indoor climate on the cost of space, productivity and sick leave in an office building: A case study. Building Environ., 41, 1961-1972.

Sadrzadehrafiei, S., Mat, K. S., Lim, C. (2011). Application of advanced glazing to mid-rise office buildings in Malaisia. In: Niola, V., Ng, K.-L. (eds.). Proceedings of World Scientific and Engineering Academy and Society (WSEAS) Conference on Environment, Ecosystems and Development (EED'11). WSEAS Press, Montreau, pp. 197-201.

Schleibinger, H., Laussmann, D., Bornehag, C.-G., Eis, D., Rueden, H. (2008). Microbial volatile organic compounds in the air of mouldy and mould-free indoor environment. Indoor Air, 18, 113-124.

Seppanen, O. A., Fisk, W. J., Mendell, M. J. (1999). Association of ventilation rates and $\mathrm{CO}_{2}$ concentrations with health and other responses in commercial and institutional buildings. Indoor Air, 9, 226-252.

Sharples, S., Lash, D. (2007). Daylight in atrium buildings: A Critical Review. Archit. Science Rev., 50 (4), 301-312.

Song, K. D. (2007). Evaluating daylighting and heating designs of a topglazed atrium space through physical scale model measurements and CFD analyses. Indoor and Built Environ., 16, 121-129.

Stavova, P., Melikov, A. K., Sundell, J., Naydenov, K. G. (2007). Air change rate measurement in apartment by $\mathrm{CO}_{2}$ method. Technika, 4, 166.

Tayyari, F., Smith, J. L. (1997). Occupational Ergonomics: Principles and Applications. Chapman \& Hall, London, 452 pp. (see Chapter 1\&19).

Tint, P., Traumann, A. (2012a). Health risk assessment in atrium-type buildings. Inter. J. Energy Environ., 6 (4), 389-396.

Tint, P., Traumann, A., Pille, V., Tuulik-Leisi, V.-R., Tuulik, V. (2012b). Computer users' health risks caused by the simultaneous influence of inadequate indoor climate and monotonous work. Agron. Res., 10, 261-268.

Vilcane, I, Urbane, V., Tint, P., Ievins, J. (2015). The comparison study of office workers' workplace health hazards in different type of buildings. Agron. Res., 13 (3), 846-855.

Voeltzel, A., Carrie, F. R. Guarracino, G. (2001). Thermal and ventilation modelling of large highly-glazed spaces. Energy Build., 33, 121-132.

Woods, A. W., Fitzgerald, S., Livermore, S. (2009). A comparison of inter pre-heating requirements for natural displacement and natural mixing ventilation. Energy Build., 41 (12), 1306-1312.

Yunus, J., Ahmad, S. S., Zain-Ahmed, A. (2010). Analysis of atrium's architectural aspects in office buildings under tropical sky conditions. In: Proceedings of International Conference on Science and Social Research. IEEE, Kuala Lumpur, pp. 536-541.

\section{DARBA VIETU ERGONOMIKAS UZLABOŠANA ĀTRIJA TIPA ĒKĀS}

Pētījuma mērḳis bija uzlabot iekštelpu gaisa kvalitāti un ergonomiku darba vietās ātrija tịpa ēkās. Ātrija tipa ēkai ir raksturīgs taisnstūrveida, slēgts pagalms ar izmēru $15 \times 30$ metri iekšpusē. Pagalma pusē jumts ir veidots no stikla un ir pārtraukums starp sienām un jumtu. Tas dod iespēju darbiniekiem ātrija slēgtās telpās elpot svaigu gaisu, tomēr pastāv problēmas, ko izraisa dabiskās gaismas trūkums, augsta $\mathrm{CO}_{2}$ koncentrācija un zema temperatūra ziemā. Pētījuma galvenie rezultāti: dizains darba vietās ir jāveic paralēli ēkas būvniecībai, vēlāk ir grūti uzlabot apstākḷus darbavietā; gaisa temperatūra darba telpās ir atkarīga no istabas vietas èkā; ziemā telpas slēgtajā ātrijā ir aukstas; $\mathrm{CO}_{2}$ un putekḷu koncentrācija pārsniedz pieḷaujamās robežas. Darba ņēmēju veselība var tikt apdraudēta, attīstoties slimo ēku sindromam. 